\title{
CRYOGLOBULINEMIA IN CHRONIC HEPATITIS C: CLINICAL ASPECTS AND RESPONSE TO TREATMENT WITH INTERFERON ALPHA AND RIBAVIRIN
}

\author{
Edison Roberto PARISE(1), Ana Cláudia de OLIVEIRA(1), Maria Lúcia FERRAZ(1,2), Aparecido Bernardo PEREIRA(2) \& Kátia Ramos LEITE(3)
}

\begin{abstract}
SUMMARY
INTRODUCTION: The main extra-hepatic manifestation of hepatitis C is mixed cryoglobulinemia (MC). The aim of this study was to evaluate its prevalence among patients with chronic hepatitis $\mathrm{C}(\mathrm{CHC})$, to correlate its presence to host and virological variables and to the response to combined therapy with interferon-alpha and ribavirin. CASUISTIC AND METHODS: 202 CHC naive patients (136 with chronic hepatitis and 66 with cirrhosis) were consecutively evaluated for the presence of cryoglobulins. Cryoprecipitates were characterized by immunoelectrophoresis and classified according to the Brouet's criteria. RESULTS: The prevalence of MC was $27 \%$ (54/202), and $24 \%$ of them (13/54) showed major clinical manifestation of the disease. Even though type III MC was more frequent (78\%), symptomatic MC was more common in type II MC. The presence of cirrhosis $(\mathrm{RR}=2.073$; IC95\% $=1.029-4.179 ; p=0.041)$, and age of the patients $(\mathrm{RR}=1.035 ; \mathrm{IC} 95 \%=1.008-1.062 ; \mathrm{p}=0.01)$ were independently associated with the presence of cryoglobulins. No relationship was found with viral load and genotype. 102 patients were treated with interferon alpha and ribavirin. Among these, 31 had MC. Sustained virological response (around 30\%) was similar in patients with and without MC ( $\mathrm{p}=0.971)$. CONCLUSION: MC represents a prevalent complication in patients with CHC, specially older and cirrhotic patients. Only $24 \%$ of these patients show clinical manifestation of the disease, specially those with type II MC. The presence of MC did not affect the response to therapy.
\end{abstract}

KEYWORDS: Mixed cryoglobulinemia; Chronic hepatitis C; Interferon and ribavirin; Cirrhosis.

\section{INTRODUCTION}

The main extra-hepatic complication caused by hepatitis $\mathrm{C}$ virus (HCV) infection is cryoglobulinemia ${ }^{26}$. The prevalence of cryoglobulinemia in chronic hepatitis $\mathrm{C}$ has been highly variable in different studies, showing frequencies ranging from $2 \%$ to $66 \%^{17,29}$. Even in the series where the frequency of cryoglobulinemia were high, only in a few cases major manifestations of the disease could be found, such as purpura; glomerulonephritis; neuropathy, and arthropathy, all of them resulting from skin and peripheral nerve vasculitis ${ }^{10,15,17,36}$.

Different studies in the literature report a great variation regarding prevalence and type of cryoglobulinemia in hepatitis $\mathrm{C}$, besides variations in the relationship between the cryoprecipitate composition and the clinical manifestations of the syndrome. These variations have been attributed to methodological aspects, geographic factors, and selection criteria of the patients ${ }^{10,15,17,36}$.

A meta-analysis ${ }^{17}$, found a relationship between cryoglobulinemia and the presence of cirrhosis, suggesting that cryoglobulinemia may be related to the progression of the hepatic disease caused by the hepatitis $\mathrm{C}$ virus.
The presence of cryoglobulinemia did not appear to influence the response of the hepatitis $\mathrm{C}$ treatment when only interferon alpha was utilized $^{8,24,28}$. However, the therapeutic response to the combined treatment of interferon and ribavirin has only been evaluated in the retreatment of non-responsive cases to a previous monotherapy treatment $t^{6,8,22}$, or in specific studies of complications of cryoglobulinemia, such as vasculitis or glomerulonephritis $1,4,5,27,37$.

The objectives of this study were to determine the prevalence of cryoglobulinemia in a group of patients with chronic hepatitis caused by the $\mathrm{C}$ virus and to correlate its presence with demographics and clinical variables of the host, cryoprecipitate characteristics, variables related to the virus, and the stage of the hepatic disease. In addition, the impact of the presence of cryoglobulinemia on the response to the treatment with interferon alpha and ribavirin was also evaluated.

\section{CASUISTIC AND METHODS}

This study evaluated 202 consecutive "naive" patients with chronic hepatitis $\mathrm{C}$ characterized by the presence of positive anti-HCV and HCV-RNA in the serum. Patients co-infected with the hepatitis B and HIV; with active alcohol consume (alcohol consumption greater than 


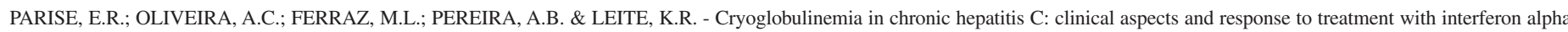
and ribavirin. Rev. Inst. Med. trop. S. Paulo, 49(2): 67-72, 2007.

$40 \mathrm{~g} /$ day) and with autoimmune hepatitis or other chronic hepatic diseases were excluded.

Aspartate-aminotransferase (AST) and alanine-aminotransferase (ALT) serum concentrations were determined through an automatic kinetic method. The genotype of the HCV-RNA was identified through restriction analysis of the amplified sequences of the non-coding 5 , region. The viral load was determined by the quantitative PCR method (Amplicor Monitor ${ }^{\circledR}$, Roche Diagnostics).

One-hundred-eighty-one out of 202 patients were submitted to liver biopsy, while the remaining 21 patients showed clinical, ultrasonography and endoscopy signs compatible with cirrhosis and due to alterations in their blood clotting ability, liver biopsy was not performed. The biopsy fragments were stained with hematoxylin and eosin (HE), Masson's trichrome and reticulin, and the disease stage was determined according to the presence or absence of hepatic cirrhosis ${ }^{18}$.

Determination and characterization of the cryoprecipitates: Blood samples were collected under appropriated conditions and stored at $4{ }^{\circ} \mathrm{C}$ for seven days. After separating the cryoprecipitates by centrifugation, its concentration was estimated by the Lowry method ${ }^{16}$. Samples with concentrations greater than $80 \mu \mathrm{g} / \mathrm{dL}$ were considered positive and the precipitates were characterized immunologically through agarose gel immunoelectrophoresis utilizing specific antisera (anti-IgG, anti-IgA, anti-IgM, anti- $\kappa$, and anti- $\lambda$ ). Cryoglobulinemias were classified according to the criteria described by BROUET et al. ${ }^{3}$.

Patients with chronic hepatitis $\mathrm{C}$ that agreed to receive treatment, signed an informed consent form and received interferon alpha $3 \mathrm{MU}$ subcutaneously, three times a week and 1.0 to $1.25 \mathrm{~g}$ of ribavirin/day for 24 or 48 weeks, according to established criteria ${ }^{32}$. Results were analyzed based upon the "intention-to-treat" basis and sustained virologic response (SVR) was indicated by undetectable levels of HCVRNA in the peripheral blood 24 weeks after stopping the treatment.

Variables analyzed: The following variables related to the presence of cryoglobulinemia were analyzed: gender; age; route of infection (parental vs non-parental); genotype and viral load; ALT levels, platelet count and presence or absence of cirrhosis.

The presence of signs and clinical symptoms associated with cryoglobulinemia were correlated to age; gender; genotype and HCV viral load; ALT levels; presence of cirrhosis and type of cryoglobulins.

Data were evaluated with the Student $t$ test and the $\chi^{2}$ test. The demographic, virological, and histological variables were submitted to logistic regression to identify independent variables associated with the presence of cryoglobulins and factors associated with the response to interferon alpha and ribavirin treatment. The level of significance considered was $0.05(5 \%)^{13}$.

\section{RESULTS}

Fifty-four $(27 \%)$ patients were positive for the presence of cryoglobulins. When comparing subjects with and without cryoglobulins, the positive cases showed older age $(55.1 \pm 1.8$ y vs $47.6 \pm 1.2 \mathrm{y} ; \mathrm{p}<$ 0.001 ), and there was no preference for gender. The groups did not differ on the form of acquiring the infection, viral load and genotype. Among the 54 patients with cryoprecipitates, 28 (52\%) presented cirrhosis; but this histological finding was present only in $26 \%$ of those 148 patients negatives for cryoglobulins $(\mathrm{p}=0.001$, Table 1$)$.

Logistic regression for the demographic, histological, and virological parameters showed that the presence of hepatic cirrhosis and the age of the subjects were the only two independent variables associated with the presence of cryoglobulinemia (Table 2).

Table 1

Demographic, histological, and virological characteristics of the hepatitis $\mathrm{C}$ carriers with and without cryoglobulinemia

\begin{tabular}{lccc}
\hline & Negative $(\mathrm{n}=148)$ & Positive $(\mathrm{n}=54)$ & $\mathrm{p}$ \\
\hline Male gender $(\%)$ & $84(57 \%)$ & $26(48 \%)$ & 0.354 \\
Age (years) & $47.6 \pm 1.2$ & $55.5 \pm 1.8$ & $0.001^{*}$ \\
Parenteral route of infection (\%) & $101(68 \%)$ & $31(57 \%)$ & 0.206 \\
ALT (x ULN) & $2.7 \pm 0.2$ & $2.6 \pm 0.2$ & 0.777 \\
Genotype 1 $(\%)$ & $95(64 \%)$ & $33(61 \%)$ & 0.813 \\
Viral load $>850.000 \mathrm{UI} / \mathrm{mL}(\%)$ & $73(49 \%)$ & $26(48 \%)$ & 0.991 \\
Cirrhosis $(\%)$ & $39(26 \%)$ & $26(48 \%)$ & $0.001^{*}$ \\
\hline
\end{tabular}

Age, platelets, and ALT with values expressed as mean \pm standard deviation. ULN $=$ upper limit of normality.

Table 2

Factors independently associated with the presence of cryoglobulinemia in patients with chronic hepatitis $\mathrm{C}$

\begin{tabular}{lccc}
\hline & Relative risk & IC 95\% & $\mathrm{p}$ \\
\hline Age & 1.035 & $1.008-1.062$ & 0.010 \\
Cirrhosis & 2.073 & $1.029-4.179$ & 0.041 \\
\hline
\end{tabular}

Gender, age, genotype, amount of virus, stage and form of infection were included in the regression analysis. 
The analysis of the cryoglobulinemic patients $(n=54)$ showed that in 13 of them (24\%) major clinical manifestations of the disease were present. Vasculitis, with or without purpura, was the most prevalent symptom (10/13), followed by peripheral neuropathy (4/13); glomerulonephritis (3/13), and arthritis, pancreatitis and Sjögren (1/ 13 each). A low degree of B-cell Lymphoma was found in two subjects that had mixed cryoglobulinemia (MC).

According to the classification of BROUET et al. ${ }^{3}$, all patients had mixed cryoglobulinemia (MC): 42/54 (78\%) had type III, while 12/54 (22\%) showed type II cryoglobulinemia. Major clinical manifestations were more frequently found among patients with type II cryoglobulinemia with only two of such patients being asymptomatic. These patients, with or without clinical manifestations, did not differ biochemically or hematologically, and were not different for characteristics related to the virus or the degree of histological lesions (Table 3).

Treatment with interferon alpha and ribavirin: A total of 102 subjects were treated with interferon alpha and ribavirin, of which 31 (30\%) were positive for cryoglobulinemia. Before treatment the groups did not differ regarding demographics and histological data and virological characteristics (Table 4$)$. The sustained virological response was similar between both groups ( $31 \%$ vs $29 \%)$.

Among the 31 subjects with cryoglobulins, eight symptomatic cases were treated. All patients had vasculitis, associated with glomerulo- nephritis in one case, and with peripheral neuropathy in three. Vasculitis was not detected during the treatment and the levels of cryoglobulins were reduced or eliminated in seven patients. Neurological symptoms became worse in two patients during treatment. The response index of these patients was $25 \%$ and did not differ statistically from that found for the asymptomatic patients $(30 \%)$.

\section{DISCUSSION}

Mixed cryoglobulinemia is relatively common in patients with chronic $\mathrm{C}$ hepatitis, with an average prevalence of $30 \%{ }^{10,15,17,26,29,36}$, but with a wide variation from $2 \%$ to $66 \%$, according to the casuistic studied $^{7,29}$.

Methodological and geographic variations as well as the degree of hepatic damage have been indicated as causes for these discrepancies ${ }^{10,15,36}$. However, since the methodology applied for cryoglobulin detection is uniform in almost all studies ${ }^{30}$, it is not likely that methodological difficulties are influencing these results. On the other hand, as is evident in almost all studies conducted, the frequency of cryoglobulinemia is directly correlated with the prevalence of patients with cirrhosis in the evaluated population ${ }^{10,15,17,21,30,33}$.

The importance of geographic variations ${ }^{15}$ could be stressed not only by the observed differences in the prevalence but also by the type of cryoglobulin found in the cryoprecipitate in different studies ${ }^{10,12,17,20,31}$.

Table 3

General characteristics, mean values of ALT, genotype, viral load, presence of cirrhosis and type of cryoglobulin presented by the cryoglobulinemic patients with and without signs/symptoms of the syndrome

\begin{tabular}{lccc}
\hline & Asymptomatics $(\mathrm{n}=41)$ & Symptomatics $(\mathrm{n}=13)$ & $\mathrm{p}$ \\
\hline Male gender $(\%)$ & $20(49 \%)$ & $6(46 \%)$ & 0.878 \\
Age (year) & $54.5 \pm 2.2$ & $58.4 \pm 2.9$ & 0.369 \\
ALT (x LSN) & $2.7 \pm 1.7$ & $1.9 \pm 0.9$ & 0.141 \\
Genotype 1 $(\%)$ & $21(51 \%)$ & $10(77 \%)$ & 0.190 \\
Viral load > 800 000 UI/mL) & $20(49 \%)$ & $6(46 \%)$ & 0.878 \\
Cirrhosis (\%) & $21(51 \%)$ & $5(38 \%)$ & 0.629 \\
Cryoglobulin type (II : III) & $2: 39$ & $10: 3$ & $<0.001$ \\
\hline
\end{tabular}

ALT- alanine-aminotransferase; Values expressed as mean \pm standard deviation.

Table 4

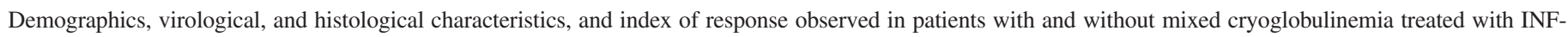
alpha and ribavirin

\begin{tabular}{|c|c|c|c|}
\hline & Cryoglobulin $-(\mathrm{n}=71)$ & Cryoglobulin $+(\mathrm{n}=31)$ & $p$ \\
\hline Age (year) & $49.6+1.6$ & $54.8+2.3$ & 0.108 \\
\hline Male Gender $(\%)$ & $43(60 \%)$ & $16(52 \%)$ & 0.533 \\
\hline Parenteral route of infection (\%) & $51(72 \%)$ & $18(58 \%)$ & 0.256 \\
\hline Genotype $1(\%)$ & $41(58 \%)$ & $20(64 \%)$ & 0.673 \\
\hline Viral load > 850000 UI/L (\%) & $42(59 \%)$ & $19(61 \%)$ & 0.986 \\
\hline Cirrhosis $(\%)$ & $45(63 \%)$ & $17(55 \%)$ & 0.554 \\
\hline SVR & $22(31 \%)$ & $9(29 \%)$ & 0.971 \\
\hline
\end{tabular}

SVR - sustained virological response 


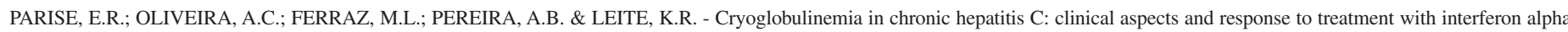
and ribavirin. Rev. Inst. Med. trop. S. Paulo, 49(2): 67-72, 2007.

In our study, and corroborating some studies previously conducted $^{10,17,20}$, a correlation between the presence of cryoglobulinemia and the age of the patient was found. The regression analysis shows that the age factor does not depend on the presence of cirrhosis and suggests that older patients would be more susceptible to develop this complication. This correlation adds a new variable to be evaluated in the studies of MC prevalence in hepatitis C. On the other hand, the correlation with cirrhosis raises the question wheter MC is a cause or consequence of cirrhosis. SIAGRIS et al. ${ }^{35}$ in logistic regression analysis identified staging score as the only independent variable associated with cryoglobulinemia, what could suggest that cryoglobulinemia results in more rapid hepatic fibrosis in $\mathrm{HCV}$ infected patients.

No relationship could be found between the presence of MC and viral load and genotype, although at least in one published paper, patients with HCV 2c genotype were at higher risk for the development of extrahepatic manifestations ${ }^{34}$.

Considering the classification according to BROUET et al. ${ }^{3}$, the polyclonal type (type III) was the most prevalent cryoglobulin found ( $78 \%$ of the patients). Major signs and symptoms related to the presence of cryoglobulin occurred in $24 \%$ of the positive subjects, resulting in a $6 \%$ overall prevalence of symptomatic cryoglobulin for all of the patients evaluated. Among the symptomatic patients, the type II cryoglobulin was significantly more prevalent (77\%). These findings corroborate with previous data by other authors that also found a greater frequency of the type II between the patients with symptomatic cryoglobulin and a greater prevalence of the type III among carriers of chronic hepatitis $\mathrm{C}^{10,17}$.

Regarding the symptoms, the cryoglobulinemic syndrome included only those that most correlated with the deposition of immunocomplexes in the different organs. General symptoms, mainly weakness and arthralgy, were excluded because they are non-specific for the cryoglobulinemic syndrome according to other studies ${ }^{2}$. Therefore, it was frequent to find more than one sign or symptom in each of the patients evaluated, and vasculitis was the most frequent sign observed in this study. The inclusion of lymphoma as a manifestation of cryoglobulin was considered since a low degree of lymphoma activity is frequently found in these patients ${ }^{9,11,14}$. Although such association is not widely accepted ${ }^{7}$, in a recent published retrospective and multicenter Italian study with 1,255 patients with $\mathrm{MC}^{25}$, found that the overall risk of non Hodgkin lymphoma in patients with $\mathrm{MC}$ is about 35 times higher than in the general population. Anyhow, the hematological manifestation was not the only clinical signs observed in the cases included in this study, since lymphoma and vasculitis with purpura were found in both cases.

Because of the relationship between hepatitis $\mathrm{C}$ and cryoglobulin, the management of the viral infection has been the therapy of choice for treating symptomatic or asymptomatic cryoglobulinemia. Several studies in the literature did not show any difference in the response to the therapy using interferon alpha, among patients with and without cryoglobulins $8,12,24,28,31$. However, the introduction of ribavirin as a therapy option for hepatitis $\mathrm{C}$, modified considerably the therapeutic response observed for patients of this disease, thus requiring a revision of the response-associated factors to the treatment ${ }^{30}$. The majority of studies that deal with the treatment of these patients with combined therapy refer to case studies or treatment-groups of symptomatic patients co-treated with corticosteroids and plasmapheresis. Some of these reports also studied patients that did not respond to or were relapsers to a previous monotherapy with interferon alpha, which most likely does not anticipate the response of subjects not previously treated ${ }^{1,4,5,6,22,27,37}$.

Among 202 patients studied, 102 completed treatment with interferon and ribavirin. In 31 patients with cryoglobulin treated with interferon and ribavirin, the response was similar to that observed in 71 patients negative for cryoglobulins in this study, and the SVR was around $30 \%$ in both cases, as described in other studies ${ }^{3,12,19,33}$. Moreover, in this study, no differences were found between symptomatic and asymptomatic patients in relation to response to combined treatment. Although only eight symptomatic patients were evaluated, the results obtained corroborated with those using the combined therapy for patients with vasculitis ${ }^{5,6,22,37}$. As reported in the literature, the majority of patients with RVS reduces or eliminates cryoglobulins during the treatment, and in these cases, there are improvements in the cutaneous lesions and renal disease, but not in the neurological symptoms $s^{5,8,37}$.

More recently, in a pilot study with eighteen $\mathrm{CHC}$ patients with $\mathrm{MC}$, treated with pegylated interferon and ribavirin, found only $44 \%$ of sustained virological response, what could suggest that this therapy is not as effective as in patients with $\mathrm{CHC}$ without cryoglobulinemia ${ }^{23}$.

In conclusion, the study of cryoglobulins in 202 patients evaluated consecutively showed a general prevalence of $27 \%$ and presence of cryoglobulinemic syndrome with major symptoms in only $6 \%$ of the cases. The prevalence was associated in an independent manner to the presence of hepatic cirrhosis and to the age of patients. Even though the type III cryoglobulin was the most prevalent, the type III cryoglobulin was associated more frequently to the presence of symptoms. The presence of this complication did not interfere in the response observed to the combined therapy of interferon alpha and ribavirin.

\section{RESUMO}

\section{Crioglobulinemia na hepatite crônica $\mathrm{C}$ : aspectos clínicos e resposta ao tratamento com interferon alfa e ribavirina}

INTRODUÇÃO: A crioglobulinemia mista (CM) representa importante complicação extra-hepática da hepatite C. Nesse estudo avaliamos sua prevelência em pacientes com hepatite $\mathrm{C}$ crônica (HCC) e relacionamos sua presença com aspectos clínicos e resposta ao tratamento com interferon alfa e ribavirina. CASUÍSTICA E MÉTODOS: 202 pacientes consecutivos com HCC (136 com hepatite crônica e 66 com cirrose) foram avaliados para a presença de CM. Os crioprecipitados foram caracterizados por imunoeletroforese e classificados de acordo com BROUET et al. RESULTADOS: A prevalência de CM nessa população foi de $27 \%$ (54/202), e, desses, $24 \%$ (13/54) apresentaram manifestações clínicas maiores da doença. Embora MC tipo III tenha sido a forma mais freqüentemente encontrada, a doença sintomática foi mais comum entre os pacientes com MC tipo II. A presença de cirrose ( $R R=2,073 ; \mathrm{IC} 95 \%=1,029$ $4,179 ; \mathrm{p}=0,041)$ e a idade do paciente $(\mathrm{RR}=1,035 ; \mathrm{IC} 95 \%=1,008$ - 
$1,062 ; \mathrm{p}=0,01)$ estiveram independentemente associadas à presença de CM. Não houve associação entre a presença de CM e genótipo ou carga viral do vírus $\mathrm{C}$. No total, 102 pacientes foram tratados com interferon alfa e ribavirina. Desses, 31 apresentavam CM. A resposta virológica sustentada (em torno de 30\%) não diferiu entre pacientes com e sem CM ( $\mathrm{p}=0,971)$. CONCLUSÃO: CM é uma freqüente complicação na HCC, especialmente em pacientes com idade avançada e com cirrose hepática. Apenas $24 \%$ desses pacientes apresentam manifestações clínicas da doença, sendo mais freqüentes entre portadores de CM tipo II. A presença de crioglobulinemia não afetou a resposta virológica ao tratamento com interferon alfa e ribavirina.

\section{REFERENCES}

1. ALRIC, L.; PLAISIER, E.; THEBAULT, S. et al. - Influence of antiviral therapy in hepatitis C virus-associated cryoglobulinemic MpGN. Amer. J. Kidney Dis., 43: 617-623, 2004

2. AMIEL, A.; KITAY-COHEN, Y.; FEJGIN, M.D. \& LISHNER, M. - Replication status as a marker for predisposition for lymphoma in patients with chronic hepatitis $\mathrm{C}$ with and without cryoglobulinemia. Exp. Hemat., 28: 156-160, 2000.

3. BROUET, J.C.; CLAUVEL, P.C.; DANON, F.; KLEIN, M. \& SELIGMAN, M. - Biological and clinical significance of cryoglobulins. A report of 86 cases. Amer. J. Med., 57: 775-788, 1974.

4. BRUCHFELD, A.; LINDAHL, K.; STAHLE, L.; SODERBERG, M. \& SCHVARCZ, R - Interferon and ribavirin treatment in patients with hepatitis $\mathrm{C}$-associated renal disease and renal insufficiency. Nephrol. Dial. Transplant., 18: 1573-1580, 2003.

5. CACOUB, P.; LIDOVE, O.; MAISONOBE, T. et al. - Interferon-alpha and ribavirin treatment in patients with hepatitis $\mathrm{C}$ virus-related systemic vasculitis. Arthritis Rheum., 46: 3317-3326, 2002.

6. CALlEJA, J.L.; ALBILlOS, A.; MORENO-OTERO, R. et al. - Sustained response to interferon- $\alpha$ or to interferon $\alpha$ plus ribavirin in hepatitis $\mathrm{C}$ virus-associated symptomatic mixed cryoglobulinaemia. Alim. Pharmacol. Ther., 13: 1179-1186, 1999.

7. CASARIL, M.; CAPRA, F. ; GABRIELLI, G.B. et al. - Cryoglobulinemia in hepatitis C virus chronic active hepatitis: effects of interferon-alpha therapy. J. Interferon Cytokine Res.,16: 585-588, 1996.

8. CRESTA, P.; MUSSET, L.; CACOUB, P. et al. - Response to interferon $\alpha$ treatment and disappearence of cryoglobulinaemia in patients infected by hepatitis $\mathrm{C}$ virus. Gut, 45: $122-128,1999$.

9. DE RE, V.; DE VITA, S.; MARZOTTO, A. et al. - Pre-malignant and malignant lymphoproliferations in an $\mathrm{HCV}$-infected type II mixed cryoglobulinemic patient are sequential phases of an antigen-driven pathological process. Int. J. Cancer, 87: 211-216, 2000.

10. DONADA, C.; CRUCITTI, A.; DONADON, V. et al. - Systemic manifestations and liver disease in patients with chronic hepatitis $\mathrm{C}$ and type II or type III mixed cryoglobulinaemia. J. viral Hepatitis, 5: 179-185, 1998.

11. EMENS, L.A. \& SULKOWSKI, M.S. - Regression of splenic lymphoma after treatment of hepatitis C virus infection. New Engl. J. Med., 347: 2168-2170, 2002.

12. FRANGEUL, L.; MUSSET, L.; CRESTA, P. et al. - Hepatitis C virus genotypes and subtypes in patients with hepatitis $\mathrm{C}$ with and without cryoglobulinemia. J. Hepat., 25: 427-432, 1996.

13. GLANTZ, A.S. - Primer of bio-statistics. 4. ed. New York, McGraw-Hill, 1992.

14. HAUSFATER, P.; ROSENTHAL, E. \& CACOUB, P. - Lymphoproliferative diseases and hepatitis C virus infection. Ann. Méd. intern., 151: 53-57, 2000.
15. HORCAJADA, J.P.; GARCIA-BENGOECHEA, M.; CILlA, G. et al. - Mixed cryoglobulinaemia in patients with chronic hepatitis $\mathrm{C}$ infection: prevalence, significance and relationship with different viral genotypes. Ann. Med., 31: 352358, 1999.

16. HUEMER, R.P. \& LEE, K.D. - Automated Lowry method for microgram protein determination. Analyt. Biochem., 37: 149-153, 1970

17. KAYALI, Z.; BUCKWOLD, V.E.; ZIMMERMAN, B. \& SCHMIDT, W.N. - Hepatitis C, cryoglobulinemia, and cirrhosis: a meta-analysis. Hepatology, 36: 978-985, 2002.

18. KNODELL, R.G.; ISHAK, K.G.; BLACK, W.C. et al. - Formulation and application of numerical scoring system for assessing histological activity in asymptomatic chronic active hepatitis. Hepatology, 1: 431-435, 1981.

19. KRYCZKA, W.; ZAREBSKA-MICHALUK, D. \& CHRAPEK, M. - Assessment of selected clinical factors as predictors of response to combined interferon-alpha plus ribavirin therapy among patients with chronic hepatitis C. Med. Sci. Monit., 9(suppl. 3): $32-35,2003$.

20. LEE, Y.H.; JI, J.D.; YEON, J.E. et al. - Cryoglobulinaemia and rheumatic manifestations in patients with hepatitis C virus infection. Ann. Rheum. Dis., 57: 728-731, 1998.

21. LUNEL, F.; MUSSET, L.; CACOUB, P. et al. - Cryoglobulinemia in chronic liver diseases: role of hepatitis C virus and liver damage. Gastroenterology, 106: 1291-1230, 1994

22. MAZZARO, C.; ZORAT, F.; COMAR, C. et al. - Interferon plus ribavirin in patients with hepatitis $\mathrm{C}$ virus positive mixed cryoglobulinemia resistant to interferon. $\mathbf{J}$. Rheumat., 30: 1775-1781, 2003.

23. MAZZARO, C.; ZORAT, F.; CAIZZI, M. et al. - Treatment with peg-interferon alpha-2b and ribavirin of hepatitis $\mathrm{C}$ virus-associated mixed cryoglobulinemia: a pilot study. J. Hepat., 43: 632-638, 2005.

24. MISIANI, R.; BELLAVITA, P.; FENILI, D. et al. - Interferon alpha 2 a therapy in cryoglobulinemia associated with hepatitis C virus. New Engl. J. Med., 330: 751$756,1994$.

25. MONTI, G.; PIOLTELLI, P.; SACCARDO, F. et al. - Incidence and characteristics of non-Hodgkin lymphomas in a multicenter case file of patients with hepatitis $\mathrm{C}$ virusrelated symptomatic mixed cryoglobulinemias. Arch. intern. Med., 165: 101-105, 2005 .

26. NOCENTE, R.; CECCANTI, M.; BERTAZZONI, G. et al. - HCV infection and extrahepatic manifestations. Hepatogastroenterology, 50: 1149-1154, 2003.

27. PARIENTE, A.; DJILLOUL, A.; CADRANEL, J.F. et al. - Treatment of chronic hepatitis $\mathrm{C}$ with interferon alpha and ribavirin. Results in "real life". Gastroent. clin. biol., 27: 590-595, 2003.

28. PELliCANO, R.; MARIETTI, G.; LEONE, N. et al. - Mixed cryoglobulinaemia associated with hepatitis $\mathrm{C}$ virus infection: a predictor factor for treatment with interferon? J. Gastroent. Hepat., 14: 1108-1111, 1999.

29. PERSICO, M. - Response to Dr Adinolfi, L.E.: Prevalence and incidence of cryoglobulins in chronic hepatitis C patients. Amer. J. Gastroent., 98: 2568-2570, 2003.

30. PERSICO, M.; DE MARINO, F.A.; DI GIACOMO RUSSO, G. et al. - Prevalence and incidence of cryoglobulins in hepatitis $\mathrm{C}$ virus-related chronic hepatitis patients: a prospective study. Amer. J. Gastroent., 98: 884-888, 2003.

31. POLZIEN, F.; SCHOTT, P.; MIHM, S.; RAMADORI, G. \& HARTMANN, H. - Interferon alpha treatment of hepatitis C-associated mixed cryoglobulinemia. J. Hepat., 27: 63-71,1997.

32. POYNARD, T.; MARCELLIN, P.; LEE, S.S. et al. - Randomised trial of interferon alpha $2 \mathrm{~b}$ plus ribavirin for 48 weeks or for 24 weeks versus interferon alpha $2 \mathrm{~b}$ plus placebo for 48 weeks for treatment of chronic infection with hepatitis $\mathrm{C}$ virus. International Hepatitis Interventional Therapy Group (IHIT). Lancet, 352: 1426-1432, 1998. 


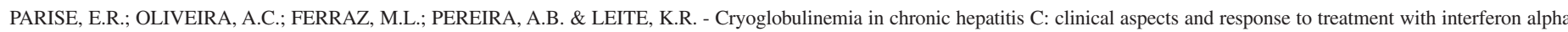
and ribavirin. Rev. Inst. Med. trop. S. Paulo, 49(2): 67-72, 2007.

33. SCHALM, S.W. WEILAND, O.; HANSEN, B.E. et al. - Interferon-ribavirin for chronic hepatitis $\mathrm{C}$ with and without cirrhosis: analysis of individual patient data of six controlled trials. European Study Group for Viral Hepatitis. Gastroenterology, 117: 408-413, 1999

34. SEBASTIANI, G.D.; BELLISAI, F.; CAUDAI, C. et al. - Association of extrahepatic manifestations with HLA class II alleles and with virus genotype in HCV infected patients. J. biol. Regul. Homeost. Agents, 19: 17-22, 2005

35. SIAGRIS, D.; CHRISTOFIDOU, M.; TSAMANDAS, A. et al. - Cryoglobulinemia and progression of fibrosis in chronic HCV infection: cause or effect? J. Infect., 49: 236-241, 2004
36. TRENDELENBURG, M. \& SCHIFFERLI, J.A. - Cryoglobulins in chronic hepatitis C virus infection. Clin. exp. Immunol., 133: 153-155, 2003.

37. ZUCKERMAN, E.; KEREN, D.; SLOBODIN, G. et al. - Treatment of refractory symptomatic hepatitis $\mathrm{C}$ virus related mixed cryoglobulinemia with ribavirin and interferon alpha. J. Rheumat., 27: 2172-2178, 2000.

Received: 29 September 2005

Accepted: 6 September 2006 